\title{
ARTIGO
}

COL https://doi.org/10.22481/praxisedu.v15i34.5805

\section{DEVIANT BEHAVIOR FORMATION FACTORS AMONG STUDENTS: AGGRESSIVE BEHAVIOR AND INTERNET RISKS}

\author{
FACTORES DE FORMACIÓN DE COMPORTAMIENTO DESVIADO ENTRE
} ESTUDIANTES: COMPORTAMIENTO AGRESIVO Y RIESGOS DE INTERNET

FATORES DE FORMAÇÃO DE COMPORTAMENTO DESVIANTE ENTRE OS ALUNOS: COMPORTAMENTO AGRESSIVO E RISCOS NA INTERNET

\begin{abstract}
Valentina B. Salakhova Ulyanovsk State University - Russia

Irina E. Sokolovskaya

Russian State Social University - Russia

Irina V. Ulyanova

Moscow University of the Ministry of Internal Affairs of Russia named after V.Y. Kikot Russia

Olga V. Karina

Balashov Institute of Saratov State University - Russia

Aleksandra I. Terekhova

RSSU (Minsk Branch), Minsk - Belarus

Resumo: A importância do problema apresentado no artigo é determinada pelo fato de que a manifestação de agressão entre crianças e adolescentes em instituições de ensino da sociedade contemporânea representa um novo desafio para a escola russa, o sistema de aplicação da lei e o sistema de apoio social no país. Federação Russa. O artigo contém os resultados da análise do comportamento agressivo entre menores como fator na formação de comportamentos desviantes de crianças e adolescentes. $\mathrm{O}$ autor fundamentou a necessidade de incluir os seguintes componentes no sistema de prevenção do impacto negativo da atividade da Internet na socialização de crianças em idade escolar: o desenvolvimento de uma cultura da informação, o desenvolvimento de qualidades pessoais que contribuam para o enfrentamento de riscos.
\end{abstract}

Palavras-chave: comportamento agressivo, riscos na Internet, comportamento desviante, ofensas, menores. 
Abstract: The importance of the problem presented in the paper is determined by the fact that the manifestation of aggression among children and teenagers in educational institutions in contemporary society represents a new challenge for the Russian school, the law enforcement system and the system of social support in the Russian Federation. The paper contains the results of the analysis of aggressive behavior among minors as a factor in the formation of deviant behavior of children and teenagers. The author has substantiated the necessity to include the following components in the system of prevention of the negative impact of Internet activity on socialization of schoolchildren: the development of an information culture, the development of personal qualities that contribute to confronting risks.

Keywords: aggressive behavior, Internet risks, deviant behavior, offenses, minors.

Resumen: La importancia del problema presentado en el documento está determinada por el hecho de que la manifestación de agresión entre niños y adolescentes en las instituciones educativas de la sociedad contemporánea representa un nuevo desafío para la escuela rusa, el sistema de aplicación de la ley y el sistema de apoyo social en el país. Federación Rusa. El documento contiene los resultados del análisis del comportamiento agresivo entre menores como un factor en la formación del comportamiento desviado de niños y adolescentes. El autor ha corroborado la necesidad de incluir los siguientes componentes en el sistema de prevención del impacto negativo de la actividad de Internet en la socialización de los escolares: el desarrollo de una cultura de la información, el desarrollo de cualidades personales que contribuyen a enfrentar los riesgos.

Palabras clave: comportamiento agresivo, riesgos de Internet, comportamiento desviado, delitos, menores.

\section{Introduction}

The manifestation of aggression among children and teens in educational institutions of contemporary society represents a new challenge for the Russian school, the law enforcement system and the system of social support in the Russian Federation. There has been an increase in violent acts committed by minors over the past decade throughout the world, that are associated with particular cruelty. Such socially dangerous manifestations, usually associated with the concepts of aggression and aggressiveness, cause serious concern. The topicality and significance of this problem is also determined by the fact that in the practice of teachers and psychologists in educational institutions, aggressive behavior of schoolchildren is one of the most common and serious problems that has numerous and diverse manifestations: conflicts 
with teachers, hostility to classmates, confrontation with parents, participation in informal groups, etc.

The concept of aggression (from the Latin "agressio" - attack, assault) is motivated destructive behavior that contradicts the norms and rules of the coexistence of people in society, damaging the objects of attack (animate and inanimate), causing physical injuries to people, negative feelings, state of tension, fear, depression, etc. (Meshcheryakov \& Zinchenko, 2003).

Aggression is premeditated actions aimed at causing harm to another person, group of people or an animal; aggressiveness is a personality trait expressed in readiness for aggression (Rean, 1999).

The whole variety of forms of aggressiveness can also be combined into heteroaggression directed towards others and auto-aggression directed to oneself (Baron \& Richardson, 1997).

The problem of aggressive behavior has been widely developed in foreign and domestic psychology (Bandura \& Walter, 1999; Furmanov, 2004). However, despite many works on the problem of aggression, there are unresolved issues in its study, since the number of manifestations of aggressive behavior observed in practical activity of school psychologists and teachers does not decline.

Aggressiveness of children and teens is defined as a personal characteristic that was formed in the process of personality development on the basis of social learning and is a manifestation of aggressive reactions. The development of aggressiveness in one's teens is determined by several interrelated groups of factors: psychobiological factors; social macro and micro-factors; psychological characteristics of personality. Manifestations of aggression in their active form are determined primarily by the conditions of education and the conditions of socialization.

However, according to a great number of experts, one of the sources of aggressiveness in children and teenagers as a form of deviant behavior is the family. The forms of manifestation of aggression in family relationships are very diverse and include direct physical or sexual violence, coldness, insults, negative assessments, personality suppression, emotional rejection of a child. Family members may exhibit aggressive behavior themselves or may reinforce the child's unwanted actions, for example, expressing pride in his victory in the fight. Various family factors, for example, conflict or an inadequate style of family upbringing, influence the formation of a child's aggressive behavior. For instance, parents who use extremely harsh punishments, use excessive control (hyper-custody) or, on the contrary, do not control the 
activities of their children (hypo-custody), are more often faced with aggression and disobedience of their children. There is also an opinion that the father's aggression towards the mother (physical or moral abuse) has a pronounced negative effect on the child. Aggressive children usually grow up in families where parents have little interest in the development of their child and prefer punishment to caring and patient explanation. In the family, the child undergoes primary socialization. It has been found that cruel punishments correlate with a high level of aggressiveness in children, and insufficient childcare, permissiveness are associated with asocial orientation. Too much freedom of the child, the inability of the parents to cope with the energetic and demanding behavior of the son and the inability to teach him the rules of behavior form a style of power domination and disobedience (Kodzhaspirov et al., 2019; Erofeeva, 2015; Salakhova et al., 2018a; Kalenik et al, 2018; Masalimova \& Chibakov, 2016; Mitin, 2016; Kalinina et al., 2018).

In general, aggressive behavior in the family is formed by three mechanisms: imitation and identification with the aggressor; a protective reaction in case of aggression directed towards the child; a protest reaction to frustration of basic needs.

As a rule, at first, while experiencing frustration, the child experiences pain, which, in the absence of understanding and mitigation, turns into disappointment and anger. Aggression attracts parents' attention, which in itself is important for the child. In addition, using aggression, the child often achieves his goals by controlling the people around. Gradually, aggression and violation of the rules begin to be systematically used as ways to obtain the desired result. Deviant behavior becomes fixed.

\section{Literature Review}

In addition, special attention should be paid to the development of information technologies and their penetration into all spheres of life. Along with the emerging opportunities, they entail the spread of new risks and threats associated with the impact of the Internet, including life threats and the involvement of minors in extremist and other dangerous groups and communities. The objectives to prevent these threats are included in the priority areas for creating an environment of a safe well-being and safe childhood and occupies a significant place in the schedule of the main activities till 2020 held in the framework of the Decade of Childhood, announced according to the Decree of the President of the Russian Federation N. 240 of May 29, 2017. 
The risks and threats that minors encounter on the Internet today are diverse. Along with the threats of developing Internet addiction, a passion of children for games on the Internet, the threats of financial fraud, new threats associated with communication on social networks are gaining momentum today, indicating a targeted destructive impact on the immature psyche of schoolchildren: these are both egregious cases of mass suicides of schoolchildren - members of the same groups in social networks, and the problems of bullying and grooming in the network, the problems of recruiting to closed communities, including extremist and other dangerous groups, etc. High rates of their spread require the immediate adoption of all possible measures to counter these threats (Salakhova \& Oschepkov, 2017).

The state and society are actively developing and implementing a system of legal measures designed to limit the distribution of dangerous content in the network, and to strengthen control over the information posted. State and public organizations conduct regular monitoring of the network. However, only prohibitive measures do not guarantee full protection of children and teenagers from the threats that their staying on the Web for many hours entail. Obviously, it is necessary to organize special psychological and pedagogical prevention of the negative impact of students' online activity on their mental and psychological health, personal well-being, which would combine the efforts of all interested institutions, and, above all, educational institutions and families (Erofeeva \& Khramtsova, 2015; Mitin et al., 2018; Salakhova et al., 2018c; Masalimova et al., 2019).

In view of the fact that the risk factors for Internet space are a relatively new risk type for minors' social adaptation, the scientific and methodological support to organize preventive work has definitely turned out to be insufficient.

The psychological literature presents studies of Internet addictions, factors and causes that influence their distribution, approaches to fight it (Voiskunovsky, 2005; Koptelova \& Popov, 2015). Relatively recently, studies have appeared on other risks in the Internet space, children and adults' perceptions of the Internet, their awareness of the means and methods of protection in the Internet space (Soldatova \& Zotova, 2013). However, the focus of science on the problem, the degree of its elaboration, remains disproportionate to the rate of spread of risks, their diversity and the severity of the harm. In these conditions, the objective of developing scientific and methodological bases to prevent Internet risks and threats becomes urgent. 


\section{Results And Discussion}

\section{Types and Characteristics of Internet Risks}

Due to the active development of cyberspace in recent decades, threats from everyday life have shifted to the online environment, having turned into Internet risks. The main target of these processes is still children and adolescents. Considering the prevention of Internet risks in the framework of the methodological bases of the cultural-historical approach (Vygotsky, 1983), we can state that the Internet environment is defined as the "tool" of getting experience by a child in a social development environment. That is, the Internet space is a zone of proximal development for the child, where difficult online situations are created that need to be solved (Soldatova et al., 2011).

The solution to these problems falls not only on the shoulders of the younger generation, but, first of all, on adults: parents, teachers and psychologists who carry out the function of upbringing in education. In this regard, it becomes necessary to identify special risk groups in the virtual world in order to ensure greater safety for minors by raising parents and teachers' awareness and their further work with teenagers and adolescents.

The following threats are the most common: threats to physical health associated with a long stay on the Web, dangerous websites, a danger of communicating with strangers in social networks, the ones related to online games, related to calls for suicidal behavior, associated with the loss of money (consumer risks), the risks of Internet addiction. A common characteristic of all these risks is the means of their implementation, namely, the Internet is the tool for their implementation.

Children following the links on the Web may be exposed to dangerous information posted on various websites. Dangerous sites containing a destructive message are related to content risks. Content risks are materials (texts, pictures, audio, video files, links to third-party resources) containing violence, aggression, eroticism and pornography, obscene language, information inciting racial hatred, propaganda of anorexia and bulimia, suicide, gambling, drugs etc. Very often, such material can come from a stranger by mail in the form of spam or messages (Soldatova et al., 2011).

Communication risks, which also include communication with strangers in social networks, can have a negative impact on the mental and, in the future, physical health of minors. As in real life, communication with strangers who pursue their own goals and commit illegal 
acts can pose a threat to children. Virtual risks do not differ much from the risks of communicating with real people who are trying to establish illegal contact. Illegal contact refers to building closer relationships between adults for the purpose of sexual exploitation of a child. A more dangerous virtual crime after making illegal contact with serious consequences is cyber bullying and cyber grooming. Harassment refers to a person's behavior that harms or causes inconvenience to another person, violating privacy, entailing criminal liability (Criminal Code of the Russian Federation, Article 137). Similarly, cyber harassment also implies a person's behavior on the Internet, which in one way or another harms another person and violates the boundaries of his personal life. Such behavior may consist of direct or indirect verbal abuse or threats, unfriendly remarks, rude jokes or insinuations, unwanted letters or calls, showing offensive or humiliating photos, intimidation. Then, when meeting in real life, this can be expressed in lascivious gestures, unnecessary touches, pats, tweaks, bumps, physical assault or other similar actions (Erofeeva et al., 2018; Salakhova et al., 2018b).

Cyber grooming is building friendly relations with a child and further making him commit any acts of a sexual nature by means of blackmail, the threat of destruction, damage or seizure of property or using the material or other dependence of a minor (Criminal Code of the Russian Federation, Article 133); commission of depraved acts without violence by a person against persons of minor age (Criminal Code, Article 135). Often, malefactors impersonate another person in order to start communicating with a child, posing as a peer or potential friend. Trying to make closer contact, the malefactor finds out the personal contacts of the child in order to continue communication in the real world and the subsequent meeting.

One of the common risks of the Web, which takes its roots from the real life of teenagers, is cyber persecution (or cyber bullying). This is the baiting of the user with messages containing insults, aggression, sexual harassment through various Internet services. In general, Internet baiting by the persecutor of a victim may take such forms as the exchange of personal information and further manipulation of it and personal contacts; intimidation; mockery imitation; hooliganism (Internet trolling); social boycott. In addition, bullying can take not only verbal forms, but also others, for example, graphic, when one user makes humiliating cartoons or photographs in such a way as to expose the "victim" in an insulting form (Help line "Children Online"). 


\section{Risks of Minors' Being Involved in Dangerous Groups and Communities}

We can identify the risk of being involved in dangerous groups and communities as a separate, most hazardous group of risks that can affect children's perception on a grand scale, (extremist groups, engaging in criminal and illegal activities, etc.). The danger of these risks lies in the fact that in the contemporary world extremism is more prevalent exactly among young people. The psyche of a teenager who is at the stage of comprehending the purpose of his life undergoes significant changes, especially in a situation where almost any information is available through the Internet. When discussing the role of education in preventing violent extremism, it is necessary to consider issues related not only to the content of education, but also to its forms, how national education systems improve access to knowledge about the values of diversity, tolerance and adoption of other cultures, as well as measures that will be needed for each population.

The problem of violent extremism has penetrated into all spheres of human activity. Since the threat of violent extremism and radicalization is a complex phenomenon, the answers are also multidimensional. An alarming signal is that many of those who joined the extremist group are often representatives of highly educated youth. Therefore, in the orientation of education, it is also crucial that young people should develop the ability to make critical judgments in order to distinguish the right from the wrong, not only in real life, but also when working on the Internet. It is necessary to give them an incentive that will help them in the educational process (Global Counter-Terrorism Forum).

Although education alone in itself cannot prevent people from becoming extremists, it can help eradicate conditions conducive to violent extremism. In order to achieve this, it is necessary that schools be a safe discussion platform where students can openly discuss acute political and religious issues to prevent the possibility of finding answers to these questions from other sources, including online ones. It is also necessary to create a multicultural learning environment and processes to ensure that students do not feel disadvantaged in school settings.

Often, teenagers face risks such as excessive use of online games, which leads to a waste of mental, physiological and financial resources in the virtual space at the expense of the means and needs of the real world. This is an increase in the amount of time spent in the Internet space at the expense of real time, a deterioration in mental and physiological health, as well as a loss of financial resources for the user of online games. High-quality online game worlds by immersing the user in virtual reality enable the user to experience the spectrum of those 
emotions that he strives to get in real life, but for some reason does not get them. The ability to feel and relive these emotions through the release of hormones in the real world encourages one to return to games again and again, gradually, however, increasing the amount of time and spending more resources to go online.

There are several types of computer games, such as local, online and network games. The essence of local games is to go through the entire stage of the game, achieve a result, after which the player receives satisfaction after completing certain stages and tasks. These are individual games with one user, where the player himself chooses the profile of a character, the complexity of the game, etc. Network games are a form of collective communication in which the same feelings and emotions develop as in a team game in reality: competition and rivalry, a sense of cohesion and unity in a team, a taste of victory, etc. Thus, several key needs are realized that can be achieved having only Internet access and a certain degree of command and game skills. In addition, the level of frustration is significantly reduced compared to the real situation, because at any time, an online game can be started anew, even if you lose.

\section{Conclusion}

A virtual world is a kind of the mirror-world for the real world, which reflects many of the functions of human life. Therefore, the modern digital world is developing according to mechanisms similar to those that operate in reality. Such mechanisms can give rise to a dependence not only on real objects, but also in the Internet space. Some researchers separately emphasize the problem of excessive use of the Internet (Soldatova \& Rasskazova, 2012), which is not only the most popular, but also the most controversial. Excessive or problematic use of the Internet can pose such a risk as Internet addiction. In true dependence, a person becomes compelled to depend on a certain type of stimulation to such an extent that constant reinforcement of this stimulation becomes the only and main idea of their life (Oschepkov \& Salakhova, 2016). Sources of addictive stimulation can be chemical (as in the case of drugs, such as alcohol, cocaine, nicotine and heroin), sensual (in cyber relationships), or even informational (as in gambling, in gaming disorder). The fact that all sources of addictive stimulation have something in common is that at first these sources provoke a strong, usually positive reaction from a potential addict, who then searches for the source of this stimulation to experience this feeling on a regular basis. In this case, the psychological dependence is formed faster than the chemical one. 


\section{Acknowledge}

This publication was prepared with the financial support of the Grant of the President (MK-2074.2019.6).

\section{REFERENCES}

1. Bandura, A. \& Walter, R. (1999). Teenage aggression. Exploring the effects of parenting and family relationships. Moscow: April Press, Publishing House EksmoPress.

2. Baron, R. \& Richardson, D. (1997). Aggression. St.Petersburg: Piter.

3. Erofeeva, M. A. (2015). Pedagogical system of students' professional readiness for gender education of schoolchildren. Moscow: Econ-inform.

4. Erofeeva, M. A. \& Khramtsova, F. (2015). Social immunity youth. Japanese Educational and Scientific Review, 1(9), 428-436.

5. Erofeeva, M. A., Stolyarova, A. N., Ilyicheva, I. M., Kodzhaspirova, G. M., Kodzhaspirov, A. Yu., Pogodina, O. A. \& Gorohova, I. V. (2018). Moral and demographic determinant of the formation of Youth Social Immunity in the sphere of higher Education. Modern Journal of Language Teaching Methods (MJLTM), 8(10), 185-197.

6. Furmanov, I. A. (2004). Psychology of children with behavioral disorders. Moscow: Vlados.

7. Kalenik, E. N., Salakhova, V. B., Mikhaylovsky, M. N., Zhelezniakova, M. E., Bulgakov, A. V. \& Oshchepkov, A. A. (2018). Psychophysiologic features and personal-adaptive potential of students with limited abilities. Electronic Journal of General Medicine; 15(6): em98

8. Kalinina, N. V., Zaretskiy, V. V., Salakhova, V. B., Artamonova, E. G., Efimova, O. I. \& Lekareva, E. E. (2018). Psychological and Pedagogical Resources of Security Provision and Prevention of Internet Risks and Life Threats Among Children and Teenagers in the Educational Environment. Modern Journal of Language Teaching Methods, 8(8), 118-129.

9. Kodzhaspirov, A. Yu., Kodzaspirova, G. M., Erofeeva, M. A., Polyakova, L. V. (2019). Formation of the personality of a safe type of behavior among school children as one of the conditions for the comfort of the educational environment. Prospects for Science and Education, 1(37), 223-235.

10. Koptelova, N. I. \& Popov, V. A. (2015). Socio-pedagogical prevention of computer addiction in adolescents in educational institutions. Young Scientist, 24, 970-973. 
11. Meshcheryakov, B. \& Zinchenko, V. (2003). Large psychological Dictionary. St.Petersburg: Prime Euroznak.

12. Masalimova, A. R. \& Chibakov, A. S. (2016). Experimental analytical model of conditions and quality control of vocational training of workers and specialists. Mathematics Education, 11(6), 1796-1808.

13. Masalimova, A. R., Mikhaylovsky, M. N., Grinenko, A. V., Smirnova, M. E., Andryushchenko, L. B., Kochkina, M. A. \& Kochetkov, I. G. (2019). The interrelation between cognitive styles and copying strategies among student youth. Eurasia Journal of Mathematics, Science and Technology Education, 15(4), em1695.

14. Mitin, S. N. (2016). Psychotherapeutic approach in the management of the development of educational systems. Simbirsk Scientific Journal Vestnik, 4(26), 31-39.

15. Mitin, S. N., Kidinov, A. V., Fedotov, S. N., Leontev, M. G., Bolotova, A. K. \& Kalinin, I. V. (2018). A Modern Models of Career Readiness. Modern Journal of Language Teaching Methods, 8(3), 68-75.

16. Oschepkov, A. A. \& Salakhova, V. B. (2016). Features of life situations of young people tending to deviant behavior. Simbirsk Scientific Journal Vestnik, 2(24), 37-41.

17. Rean, A. A. (1999). Psychology of studying personality. Moscow: Publishing house Mikhailov V.A.

18. Salakhova, V. B., Belinskaya, D. B., Erofeeva, M. A., Ulyanova I. V., Zotova, L. E., Khammatova, R. S. \& Mizonova, O. V. (2018a). Modern methods of diagnosing addiction to psychoactive substances: neurophysiological aspects. Electronic Journal of General Medicine, 15(6), 94-106.

19. Salakhova, V. B. \& Oschepkov, A. A. (2017). Peculiarities of social groups of teenagers with deviant orientation. Simbirsk Scientific Journal Vestnik, 2(28), 46-54.

20. Salakhova, V. B., Sidyacheva, N. V., Zotova, L. E., Klepach, Y. V., Rusyaeva, T. A., Belova, T. A. \& Buevich, S. Y. (2018b). Specific Features of Normative Ideals and Individual Priorities of the Deviant Personality. Modern Journal of Language Teaching Methods, 8(5), 232-242.

21. Salakhova, V. B., Zaretskiy, V. V., Kalinina, N. V., Artamonova, E. G., Efimova, O. I. \& Lekareva, E. E. (2018c). Existential Psycho-Correction of the Value-Meaning Sphere of the Personality of Adolescents with Deviant Behavior. Modern Journal of Language Teaching Methods, 8(6), 294-302.

22. Soldatova, G. V. \& Rasskazova, E. I. (2012). How to help them. Child on the Internet: prohibit, observe or explain? Children in the information society, 10, 26-33.

23. Soldatova, G. V., Zotova, E. Yu., Chekalina, A. I., Gostimskaya, O. S. (2011). Caught by the same network: a socio-psychological study of the ideas of children and adults about the Internet. Moscow: Internet Development Fund.

24. Soldatova, G. \& Zotova, E. (2013). Coping with online risks: the experience of Russian schoolchildren. Journal of Children and Media, 7(1), 44-59.

25. Voiskunovsky, A. E. (2005). Actual problems of psychology from the Internet. Psychological journal, 5, 90-100. 
26. Vygotsky, L. S. (1983). Diagnosis of development and pedological clinic of a difficult childhood. Moscow: Pedagogy.

\section{SOBRE OS AUTORES:}

\section{Valentina B. Salakhova}

$\mathrm{PhD}$ in Psychology, Associate Professor of Department of Psychology and Pedagogy, Faculty of Humanities, Ulyanovsk State University, Ulyanovsk, Russia. E-mail: valentina_nauka@mail.ru

iD http://orcid.org/0000-0002-5056-6518

\section{Irina E. Sokolovskaya}

Doctor of Psychology, Professor, Professor of Social, General and Clinical Psychology, Faculty of Psychology, Russian State Social University, Moscow, Russia. E-mail: i.e.sokol@ yandex.ru iD http://orcid.org/0000-0003-3451-0298

\section{Irina V. Ulyanova}

Doctor of Pedagogy, Professor, Professor of Department of Pedagogy, Faculty of Performance, Moscow University of the Ministry of Internal Affairs of Russia Named After V.Y. Kikot, Moscow, Russia. E-mail: iva2958@mail.ru

iD http://orcid.org/0000-0002-8603-0213

\section{Olga V. Karina}

$\mathrm{PhD}$ in Psychology, Associate Professor, Head of the Department of pedagogics and psychology, Faculty of Psychology and Pedagogy, Balashov Institute of Saratov State University, Saratov, Russia. E-mail: karina_olga@mail.ru

iD http://orcid.org/0000-0002-6632-8258

\section{Aleksandra I. Terekhova}

$\mathrm{PhD}$ in Economics, Associate Professor, Head of the Department of Management and Social Work at Russian State Social University - RSSU (Minsk branch), Minsk, Belarus. E-mail: temp17@yandex.ru

(iD) http://orcid.org/0000-0003-1957-5683

Recebido em: 25 de outubro de 2019 Aprovado em: 10 de novembro de 2019 Publicado em: 25 de novembro de 2019 